\title{
Association Between Uncoupling Protein 3 Gene and Obesity-Related Phenotypes in the Québec Family Study
}

\author{
Christian-Marc Lanouette, ${ }^{1}$ Jean-Paul Giacobino, ${ }^{2}$ Louis Pérusse, ${ }^{1}$ Michel Lacaille, ${ }^{1}$ Cédric Yvon, ${ }^{2}$ \\ Monique Chagnon, ${ }^{3}$ Françoise Kuhne, ${ }^{2}$ Claude Bouchard, ${ }^{3}$ Patrick Muzzin, ${ }^{2}$ and Yvon C. Chagnon ${ }^{1}$ \\ ${ }^{1}$ Physical Activity Sciences Laboratory, Division of Kinesiology, Department of Social and Preventive \\ Medicine, Faculty of Medicine, Laval University, Ste-Foy, Québec, Canada \\ ${ }^{2}$ Department of Medical Biochemistry, Faculty of Medicine, University of Geneva, Geneva, Switzerland \\ ${ }^{3}$ Pennington Biomedical Research Center, Louisiana State University, Baton Rouge, Louisiana, USA \\ Accepted April 5, 2001
}

\begin{abstract}
Background: UCP3 is a mitochondrial membrane transporter that is postulated to uncouple oxidative phosphorylation from ATP synthesis producing heat instead of ATP. Human UCP3 is mainly expressed in skeletal muscle, which plays an important role in energy homeostasis and substrate oxidation. Therefore, UCP3 is a good candidate gene for obesity.

Materials and Methods: We analyzed, among 734 subjects from the Québec Family Study, a new GA repeat microsatellite located in intervening sequence (IVS) 6 (GAIVS6) in UCP3 gene, and two already described restriction fragment length polymorphisms (RFLP) Y210Y $(\mathrm{C} \rightarrow \mathrm{T})$ and V102I $(G \rightarrow A)$. Covariance analysis across genotypes for different adiposity, resting energy expenditure, and glucose metabolism variables was undertaken with age and sex, plus body fat and body mass for nonadiposity phenotypes, as covariates.
\end{abstract}

Results: We found strong associations between GAIVS6 and body mass index $(p=0.0001)$, fat mass $(p=0.0005)$, percentage body fat $(p=0.0004)$, the sum of six skinfold thickness $(p=0.0001)$, and leptin level $(p=0.0001)$. Homozygote for the GAIVS6 $240 \mathrm{bp}$ alleles (15\% frequency in QFS) showed higher adiposity than subjects with the GAIVS6 $238 \mathrm{bp}$ allele (70\% in QFS). The exons, the 5' untranslated region (UTR), and the exon-intron junctions of UCP3 gene from subjects homozygote for either GAIVS6 $238 \mathrm{bp}$ or $240 \mathrm{bp}$ alleles were sequenced in search for mutations. Variants 5'UTR $-55 \mathrm{C} \rightarrow \mathrm{T}$ and $\mathrm{Y} 210 \mathrm{Y}(\mathrm{C} \rightarrow \mathrm{T})$ were detected, whereas IVS4-36C $\rightarrow \mathrm{T}$ was uncovered, but no new exonic or splice junction mutation was observed. RFLP Y210Y $(\mathrm{C} \rightarrow \mathrm{T})$ was not associated to adiposity in QFS; V102I $(\mathrm{G} \rightarrow \mathrm{A})$ showed no variation.

Conclusion: Our results suggest that some alleles of UCP3 are involved in the etiology of human obesity.

\section{Introduction}

The prevalence of obesity has increased considerably over the past 20 years and represents a major health burden in industrialized societies, particularly from Europe and North America. Obesity is a risk factor for cardiovascular diseases, diabetes, hypertension, and also for some types of cancer $(1,2)$. Obesity is a multifactorial disease with genetic and environmental origins (3), resulting from an imbalance between energy intake and expenditure. Several pathways are involved in the regulation of energy balance including those with ATPases and uncoupling proteins (UCPs).

UCPs are a family of inner membrane proteins of mitochondria that uncouple oxidative phosphorylation from the cellular respiratory chain and produce heat instead of ATP (4). UCP1, located on chromosome $4 \mathrm{q} 32$, is expressed in human newborn brown

Address correspondence and reprint requests to: Yvon C. Chagnon, PhD, Physical Activity Sciences Laboratory, Kinesiology, PEPS, Laval University, Ste-Foy, Québec, G1K 7P4 Canada. Phone: 418-656-2131 ext. 3051; Fax: 418-656-2442; e-mail: Yvon.Chagnon@kin.msp.ulaval.ca adipose tissue only (4). UCP2 and UCP3 showed $55 \%$ (5) and $56 \%$ (6) amino acid identity with UCP1, respectively. They were located on chromosome llq13 with only 7 kilobases $(\mathrm{kb})$ separating the two genes (7). In contrast to UCP1, UCP2 is widely expressed in the majority of human tissues (5), whereas UCP3 is mainly expressed in skeletal muscle (6). Studies using transfected yeast and cells in culture support the hypothesis that UCP3 has an uncoupling activity (for a review see (8)). Long $\left(\mathrm{UCP}_{\mathrm{L}}\right)$ and short $\left(\mathrm{UCP}_{\mathrm{S}}\right)$ isoforms of UCP3 have been described that originate from alternative transcripts of the gene $(6,9)$.

Skeletal muscle plays an important role in energy homeostasis and substrate oxidation (8), and it may contributes as much as $40 \%$ of whole-body, adrenaline-induced thermogenesis (10). Mice overexpressing human UCP3 in muscle were shown to be hyperphagic but lean (11). On the other hand, no phenotypic difference between UCP3 knock-out and control mice was observed $(12,13)$, but alternative compensatory mechanisms cannot be excluded.

Samec et al. (14) suggested a functional role for UCP2 and UCP3 in regulation of lipids as fuel 
substrate rather than as regulators of thermogenesis. Supporting this hypothesis, it was reported recently that fatty acids regulate UCP3 mRNA expression in human skeletal muscle in vivo (15). Comuzzie et al. (16) excluded, in Mexican Americans, the chromosomal region containing UCP2 and UCP3 as having an effect on obesity-related phenotypes at effect size of $10 \%$ or greater. Nevertheless, Schrauwen et al. (17) observed a negative correlation in Pima Indians between $\mathrm{UCP}_{\mathrm{L}}$ and $\mathrm{UCP}_{\mathrm{S}}$ and body mass index (BMI), and a positive correlation between $U C P 3_{L}$ and metabolic rate during sleep. A polymorphism in the splice donor junction of exon 6 was reported in African Americans $(18,19)$. It resulted in a decrease in $\mathrm{UCP} 3_{\mathrm{L}} / \mathrm{UCP} 3_{S}$ ratio in skeletal muscle (19). This polymorphism was found to be either associated with a decreased basal fat oxidation rate and an increased respiratory quotient (18) or with no change in body composition (19).

Urhammer et al. (20) detected in the UCP3 gene of Caucasians, nucleotide substitutions in intron regions, two silent amino acid variants (Y99Y and Y200Y), and the replacement of a glycine with a serine in exon 3 (G84S). A V102I mutation was also described $(18,19)$. None of these changes was associated with obesity phenotype. Walder et al. (21) also reported that the UCP3 Y99Y variant was not associated with metabolic rate or obesity, but Otabe et al. (22) reported a weak association between Y99Y polymorphism and obesity, and between a Y210Y polymorphism and diabetes. Eventually, a 5'UTR-55 variant was described that was found to be associated with a decreased effect of physical activity on BMI (23).

Altogether, the results of UCP3 genetic studies are rather controversial and only weak associations have been until now described between some UCP3 variants and obesity traits. In the present study, we analyzed, in relation to adiposity, energy expenditure, and glucose homeostasis, the effects of different UCP3 polymorphisms in the Québec Family Study (QFS).

\section{Materials and Methods}

Subjects and Phenotypes

The QFS cohort has been previously described (24). Caucasian nuclear families from the greater Québec City area were tested for a battery of morphometric and physiologic variables. Blood samples were obtained for various biochemical assays and permanent lymphoblastoid cell lines were established for the extraction of DNA. Only subjects 18 years of age and older were retained for the present study. A total of 734 subjects (41 grandparents, 316 parents, and 376 adult offspring) from 171 families were available for the study. Dependent variables included the BMI (weight $[\mathrm{kg}]$ divided by height $\left[\mathrm{m}^{2}\right]$ ), the percent body fat (\%FAT) estimated from body density measurements obtained by underwater weighing
(25) and the equation of Siri (26), and the fat mass (FM in kg) and fat-free mass (FFM in kg) calculated from percent body fat and body weight. Subcutaneous fat (in $\mathrm{mm}$ ) was estimated by the sum of six skinfold thickness (SF6 $=$ abdominal, subscapular, suprailiac, medial calf, triceps, and biceps). Respiratory quotient (RQ) and resting metabolic rate (RMR) were assessed in a fasted state by indirect calorimetry over a 30-min period using an opencircuit system with a ventilated hood, with data from the last $10 \mathrm{~min}$ being used for the calculation (27). Plasma levels of glucose, insulin, and leptin were measured in the morning after a 12-hr overnight fast. Radioimmunoassay was used to measure insulin with a polyethylene glycol precipitation (28), and to measure leptin (Linco, St-Charles, MO, USA) in which the lowest quantity detectable was $0.5 \mathrm{ng} / \mathrm{ml}$. Glucose was measured enzymatically (29). Identification of a GA Dinucleotide Repeat Microsatellite
Marker in Intervening Sequence 6 (GAIVS6) of UCP3

A genomic DNA sample from the Centre d'Étude du Polymorphisme Humain (CEPH) families was used for the polymerase chain reaction (PCR) amplification of the UCP3 gene as previously described (30). Sequencing of the amplified product revealed a potentially polymorphic DNA sequence with a structure of $(A)_{10}(\mathrm{GA})_{7}$ in the intron 6 of UCP3 (GAIVS6). To confirm the polymorphism, genotyping was performed in 19 CEPH families by PCR as follows. The upstream and downstream primers were 5'-TAGAACTGTGAGAATTCGCTGC-3' and 5'ACATCAGGTGGAGTGCTAGG-3', respectively, and the latter was labeled with $\left[\gamma^{32} \mathrm{P}\right]$ ATP and T4 polynucleotide kinase. PCR was performed in a $15-\mu$ l reaction mixture containing $50 \mathrm{ng}$ of human genomic DNA in $20 \mathrm{mM}$ of Tris- $\mathrm{HCl}$ (pH 8.4), $50 \mathrm{mM}$ of $\mathrm{KCl}, 1.5 \mathrm{mM}$ of $\mathrm{MgCl}_{2}, 0.1 \mu \mathrm{M}$ of each primer, $100 \mu \mathrm{M}$ of each dNTP, and 0.75 units of Taq DNA polymerase, and with the following conditions: $3 \mathrm{~min}$ at $94^{\circ} \mathrm{C}$, followed by 33 cycles for $45 \mathrm{sec}$ at $94^{\circ} \mathrm{C}, 30 \mathrm{sec}$ at $57^{\circ} \mathrm{C}$, and $30 \mathrm{sec}$ at $72^{\circ} \mathrm{C}$, and one cycle for $5 \mathrm{~min}$ at $72^{\circ} \mathrm{C}$. PCR products were separated by electrophoresis on a $6 \%$ denaturing urea/ polyacrylamide gel and detected by autoradiography on Kodak X-OMAT film. Three different alleles with size of 238,240 , and 242 bp were detected and sequenced. The 238-, 240-, and 242-bp alleles had $(\mathrm{A})_{10}(\mathrm{GA})_{5},(\mathrm{~A})_{10}(\mathrm{GA})_{6}$, and $(\mathrm{A})_{10}(\mathrm{GA})_{7}$ structures, respectively. Additionally, $280 \mathrm{bp}$ of the 5'UTR, $127 \mathrm{bp}$ upstream from exon 2, and all exons with their exon-intron junctions of five subjects homozygote for either GAIVS6 238 bp or $240 \mathrm{bp}$ alleles were sequenced in search for mutations.

\section{Genotyping of GAIVS6 Microsatellite in the Québec Family Study}

Genomic DNA was prepared from permanent lymphoblastoid cells by the proteinase $\mathrm{K}$ and phenol/ chloroform technique. DNA was dialyzed four times 
against TE buffer (10 mM of Tris, $1 \mathrm{mM}$ of EDTA, $\mathrm{pH}$ 8.0) for $6 \mathrm{hr}$ each time at $4^{\circ} \mathrm{C}$ and ethanol precipitated. PCR was performed in $10 \mu \mathrm{l}$ of reaction mixture containing $100 \mathrm{ng}$ genomic DNA, $40 \mathrm{nM}$ of untagged primer, and $10 \mathrm{nM}$ of infrared tagged primer (Licor, Lincoln, Nebraska, USA), $125 \mu \mathrm{M}$ of dNTPs, and $0.3 \mathrm{U}$ of Taq polymerase in PCR buffer (Roche Diagnostics Canada Laval, Qe, Canada). Primers used were the same as those previously described. PCR conditions were: 1 cycle at $93^{\circ} \mathrm{C}$ for $5 \mathrm{~min}, 30$ cycles at $94^{\circ} \mathrm{C}$ for $20 \mathrm{sec}$, and at $60^{\circ} \mathrm{C}$ for $1 \mathrm{~min}$ (Ericomp, San Diego, CA, USA). GAIVS6 microsatellite dinucleotide repeat was analyzed using automatic DNA sequencers and SAGA genotyping software (Licor). Genotypes were imported electronically directly in a local database named GENEMARK where a procedure to check for Mendelian inheritance incompatibilities within families has been developed. Subjects showing incompatibilities were reanalyzed completely (i.e., from PCR to genotyping).

\section{Restriction Fragment Length Polymorphism}

Two other polymorphisms were studied: a valine to isoleucine substitution at amino acid 102 $(\mathrm{V} 102 \mathrm{I}(\mathrm{G} \rightarrow \mathrm{A}))(18,19)$, and a $\mathrm{C}$ to $\mathrm{T}$ nucleotide transition in tyrosine 210 codon $(\mathrm{Y} 210 \mathrm{Y}(\mathrm{C} \rightarrow \mathrm{T}))(22)$. For both polymorphisms, primers were the same as those previously described by Chung et al. (19). For $\mathrm{V} 102 \mathrm{I}(\mathrm{G} \rightarrow \mathrm{A})$ polymorphism, PCR conditions were 1 cycle at $94^{\circ} \mathrm{C}$ for $5 \mathrm{~min} ; 40$ cycles of $94^{\circ} \mathrm{C}$ for $30 \mathrm{sec}$, $52^{\circ} \mathrm{C}$ for $30 \mathrm{sec}$, and $72^{\circ} \mathrm{C}$ for $45 \mathrm{sec}$; and 1 cycle at $72^{\circ} \mathrm{C}$ for $10 \mathrm{~min}$. PCR product $(100 \mathrm{bp})$ was digested with $5 \mathrm{U}$ of Tthlll I for $5 \mathrm{hr}$ at $65^{\circ} \mathrm{C}$. Only the V102(G) allele, giving DNA fragments of 80 and $20 \mathrm{bp}$, was found in QFS subjects; the I102(A) allele, giving a fragment of $100 \mathrm{bp}$, was not observed. For the $\mathrm{Y} 210 \mathrm{Y}(\mathrm{C} \rightarrow \mathrm{T})$ variant, PCR conditions were 1 cycle at $94^{\circ} \mathrm{C}$ for $5 \mathrm{~min} ; 40$ cycles of $94^{\circ} \mathrm{C}$ for $30 \mathrm{sec}, 53^{\circ} \mathrm{C}$ for $30 \mathrm{sec}$, and $72^{\circ} \mathrm{C}$ for $45 \mathrm{sec}$; and 1 cycle at $72^{\circ} \mathrm{C}$ for $10 \mathrm{~min}$. The 130-bp PCR product was digested with $5 \mathrm{U}$ of Rsa I at $37^{\circ} \mathrm{C}$ overnight. The Y210(C) allele gave fragments of 110 and $20 \mathrm{bp}$, and the $\mathrm{Y} 210(\mathrm{~T})$ allele of $130 \mathrm{bp}$. DNA fragments were resolved on a $3 \%$ agarose gel and visualized with ethidium bromide. All PCR reactions were performed in a GeneAmp PCR system 9600 (Perkin Elmer, Foster City, CA, USA) and Taq DNA polymerase was purchased from QIAGEN (Santa Clara, CA, USA).

\section{Sequencing of UCP3 Exons and 5'UTR}

The seven exons and the intron-exon junctions of UCP3 (GenBank accession number AF127916) were amplified by PCR and sequenced using the ABI377 sequencer.

\section{Statistical Analysis}

Phenotypic differences across genotypes were tested on all subjects using covariance analysis with age, age $^{2}$, age ${ }^{3}$, sex, plus BMI for RQ and RMR, and SF6 for log insulin. Fisher's LSD test was used to identified the pairs that differed; LSD test was performed only when the ANCOVA $p$-value was smaller than 0.05. Because the frequencies of alleles 236, 244, and $256 \mathrm{bp}$ of GAIVS6 were less than $1 \%$, they were grouped with other genotypes for analysis. Heterozygotes for these alleles were grouped with the homozygotes for the other alleles, whereas no homozygote was observed. The SAS package (version 6.12) for the PC was used for the analysis.

The use of related subjects can be explained as follows. It is commonly believed that the relatedness of the subjects in family study cohorts may cause problems in association analyses. However, a recent simulation study (Province et al., unpublished data) suggests this is not the case. The problem is that within person effects violate the basic independent, identically distributed (i.i.d.) errors assumption of classical statistical theory. Familial clusters of residuals are statistically independent but the model errors for individuals within the same family are often dependent. In the Province et al. simulation study, the data were analyzed by four methods, and the least squares method used in the present report was one of them; the other three methods treated dependencies in different ways. Two major findings are pertinent here: First, failure to incorporate dependencies did not induce any bias. Second, for moderate familial correlations as seen in most family studies (including the current one), ignoring the dependencies by using ANOVA performed quite well. The only negative impact was a small reduction in power. The standard errors are slightly larger, but type I error was unaffected. Given this, we do not believe that the dependencies or relatedness of the subjects in families cause any real problems in this type of analysis. We have already successfully used this statistical approach in some recent papers $(31,32)$.

\section{Results}

We uncovered a new polymorphism located in the sixth intron of the UCP3 gene. We observed in QFS six different alleles of $236(0.3 \%), 238(69.8 \%), 240$ $(15.2 \%), 242(14.3 \%), 244(0.2 \%)$, and $256(0.3 \%)$ bp. GAIVS6 was shown to follow the Hardy-Weinberg law (chi-square of 5.58 and $p$-value 0.13 with 3 degrees of freedom). As shown in Table 1, the frequency of allele 238 is higher in normal weight, overweight, and obese subjects (BMI $<35 \mathrm{~kg} / \mathrm{m}^{2}$ ) then in very obese subjects (BMI $\left.>35 \mathrm{~kg} / \mathrm{m}^{2}\right)$ (70-73\% versus $55 \%)$. Accordingly, the $238-238$ genotype is the most common genotype in QFS showing the lowest frequency in very obese subjects $(34 \%$ vs $52-54 \%)$. In contrast, the 240 -bp allele showed an increasing frequency from normal and overweight (BMI $\left.<30 \mathrm{~kg} / \mathrm{m}^{2}\right)$, to obese $(30<$ BMI $<$ $\left.35 \mathrm{~kg} / \mathrm{m}^{2}\right)$, and very obese subjects $(13 \%$ versus $20 \%$ versus $26 \%$ ) with frequencies of the 240-240 genotype ranging from $2-3 \%$, to $7 \%$ and $13 \%$, respectively. 
Table 1. Percentage $(N)$ of the different alleles and genotypes for the GAIVS6 microsatellite of UCP3 gene in QFS by BMI status $\left(\mathrm{kg} / \mathrm{m}^{2}\right)$.

\begin{tabular}{|c|c|c|c|c|}
\hline Allele & BMI <25 & BMI 25-29.9 & BMI 30-34.9 & $\mathrm{BMI} \geq 35$ \\
\hline 236 & $<1 \%$ & $<1 \%$ & $<1 \%$ & $<1 \%$ \\
\hline 238 & $73 \%(523)$ & $72 \%(278)$ & $70 \%$ & $55 \%(107)$ \\
\hline 240 & $13 \%(90)$ & $13 \%(49)$ & $20 \%(33)$ & $26 \%(51)$ \\
\hline 242 & $14 \%(102)$ & $15 \%(59)$ & $10 \%(16)$ & $17 \%$ \\
\hline 244 & $<1 \%$ & $<1 \%(0)$ & $<1 \%(0)$ & $<1 \%(0)$ \\
\hline 256 & $<1 \%$ & $<1 \%$ & $<1 \%(0)$ & $1 \%(2)$ \\
\hline Genotype & BMI $<25$ & BMI 25-29.9 & BMI 30-34.9 & $\mathrm{BMI} \geq 35$ \\
\hline $236-238$ & $<1 \%(1)$ & $<1 \%(1)$ & $1 \%(1)$ & $1 \%(1)$ \\
\hline $238-238$ & $53 \%(189)$ & $54 \%(105)$ & $52 \%(43)$ & $34 \%(33)$ \\
\hline $238-240$ & $18 \%(66)$ & $16 \%(30)$ & $22 \%(18)$ & $19 \%(18)$ \\
\hline $238-242$ & $21 \%(77)$ & $17 \%$ & $13 \%(11)$ & $22 \%(21)$ \\
\hline $238-244$ & $<1 \%$ & $<1 \%$ & $0 \%(0)$ & $1 \%(1)$ \\
\hline $238-256$ & $<1 \%(1)$ & $0 \%(0)$ & $0 \%(0)$ & $0 \%(0)$ \\
\hline $240-240$ & $2 \%(7)$ & $3 \%(6)$ & $7 \%(6)$ & $13 \%(13)$ \\
\hline $240-242$ & $2 \%(8)$ & $4 \%(7)$ & $4 \%(3)$ & $6 \%(6)$ \\
\hline $240-244$ & $<1 \%$ & $0 \%(0)$ & $0 \%(0)$ & $1 \%(1)$ \\
\hline $242-242$ & $2 \%(8)$ & $4 \%(8)$ & $1 \%(1)$ & $3 \%(3)$ \\
\hline $242-244$ & $<1 \%$ & $0 \%(0)$ & $0 \%(0)$ & $0 \%(0)$ \\
\hline
\end{tabular}

For chi-square test among categories, genotypes with rare alleles $(236,244$, and 256) were pooled (see text).

Chi-square for allele frequencies: $\chi^{2}=33.8$ and $p=0.001$; for genotype frequencies: $\chi^{2}=40.1$ and $p=0.001$.

When compared among the different BMI categories, allele as genotype frequencies were found to be highly statistically different $(p=0.001$ for both) between BMIs.

Significant evidence of association $(0.0001 \leq$ $\mathrm{p} \leq 0.05)$ were observed between the GAIVS6 polymorphism and obesity-related phenotypes (Table 2). Subjects carrying the 240 -bp allele, but not the 238-bp allele (240-240 and 240-242 genotypes), showed higher values for BMI, SF6, FM, \%FAT, and leptin, and a lower RQ value, compared to the 238-bp carriers (238-238, 238-240, 238-242 genotypes). Other phenotypes studied (insulin, glucose, RMR, FFM) did not show any significant association with GAIVS6, or with the other UCP3 polymorphisms studied (data not shown). When individual allele effects were compared by grouping genotypes either according to the 238-bp (Table 3 ) or 240-bp (Table 4) alleles, stronger associations were observed. For instance, carriers of the 238-bp allele showed lower values than noncarrier $(0.0001 \leq \mathrm{p} \leq 0.0005)$ for BMI $(-12 \%)$, SF6 $(-21 \%)$, FM $(-23 \%), \%$ FAT $(-14 \%)$, and leptin $(-37 \%)$, whereas association with RQ disappeared (Table 3). Inversely, homozygotes for the 240-bp allele showed higher values $(0.0001 \leq \mathrm{p} \leq$ $0.002)$ for BMI $(+18 \%)$, SF6 $(+39 \%)$, FM $(+42 \%)$, $\%$ FAT $(+24 \%)$, and leptin $(+57 \%)$, with a trend $(p=$ $0.11)$ for a lower RQ $(-2 \%)$ (Table 4$)$. No significant result was observed for the $242 \mathrm{bp}$ allele (data not shown). When corrected for SF6, results for leptin did not remain significant (results not shown). These results suggest that the 240 -bp allele, in the absence of the 238-bp allele, favor fat accumulation.

We also analyzed two restriction fragment length polymorphisms (RFLPs) in the coding region of UCP3. None of the 734 subjects showed variation for the exon 3 V $102 \mathrm{I}(\mathrm{G} \rightarrow \mathrm{A})$ polymorphism located in exon 3. On the other hand, for the exon $5 \mathrm{Y} 210 \mathrm{Y}(\mathrm{C} \rightarrow \mathrm{T})$ polymorphism located in exon $5,31 \%$ of the population were homozygous for the Y210(T) allele, $47 \%$ were heterozygous $\mathrm{Y} 210(\mathrm{C}) / \mathrm{Y} 210(\mathrm{~T})$, and $22 \%$ were homozygous for the Y210(C) allele. However, no association was found between Y210Y $(\mathrm{C} \rightarrow \mathrm{T})$ and any of the studied phenotypes. Haplotypes derived from the GAIVS6 and Y210Y $(\mathrm{C} \rightarrow \mathrm{T})$ polymorphisms gave similar associations to those obtained when considering GAIVS6 alone (data not shown). 
Table 2. Covariance analysis of the mean value ( \pm standard error) for the phenotypes among the six genotypes of the GAIVS6 microsatellite of UCP3 gene in QFS.

\begin{tabular}{|c|c|c|c|c|c|c|c|}
\hline \multirow[b]{2}{*}{ Phenotypes } & \multicolumn{6}{|c|}{ Genotypes } & \multirow[b]{2}{*}{$p$} \\
\hline & $238-238$ & 238-240 & 238-242 & $242-242$ & 240-242 & $240-240$ & \\
\hline $\begin{array}{l}\text { BMI } \\
\left(\mathrm{kg} / \mathrm{m}^{2}\right)\end{array}$ & $\begin{array}{c}26.70 \pm 0.38 \\
(347) \\
c\end{array}$ & $\begin{array}{c}27.10 \pm 0.63 \\
(123) \\
b, c\end{array}$ & $\begin{array}{c}26.80 \pm 0.60 \\
(135) \\
b, c\end{array}$ & $\begin{array}{c}27.90 \pm 1.53 \\
(21) \\
b, c\end{array}$ & $\begin{array}{c}30.30 \pm 1.46 \\
(23) \\
a, b\end{array}$ & $\begin{array}{c}31.80 \pm 1.19 \\
(35) \\
a\end{array}$ & 0.0006 \\
\hline $\begin{array}{l}\text { SF6 } \\
(\mathrm{mm})\end{array}$ & $\begin{array}{c}118.20 \pm 3.30 \\
(332) \\
c\end{array}$ & $\begin{array}{c}120.10 \pm 5.53 \\
(118) \\
b, c\end{array}$ & $\begin{array}{c}114.50 \pm 5.32 \\
(128) \\
c\end{array}$ & $\begin{array}{c}118.70 \pm 13.46 \\
(20) \\
b, c\end{array}$ & $\begin{array}{c}151.60 \pm 12.80 \\
(22) \\
a, b\end{array}$ & $\begin{array}{c}165.00 \pm 10.80 \\
(31) \\
a\end{array}$ & 0.0002 \\
\hline $\begin{array}{l}\text { FM } \\
(\mathrm{kg})\end{array}$ & $\begin{array}{c}21.20 \pm 0.73 \\
(300) \\
b\end{array}$ & $\begin{array}{c}21.30 \pm 1.23 \\
(106) \\
b\end{array}$ & $\begin{array}{c}20.10 \pm 1.18 \\
(115) \\
b\end{array}$ & $\begin{array}{c}25.00 \pm 3.28 \\
(15) \\
a, b\end{array}$ & $\begin{array}{c}25.70 \pm 3.06 \\
(17) \\
a, b\end{array}$ & $\begin{array}{c}30.30 \pm 2.70 \\
(22) \\
a\end{array}$ & 0.01 \\
\hline$\%$ FAT & $\begin{array}{c}27.40 \pm 0.49 \\
(300) \\
b\end{array}$ & $\begin{array}{c}27.40 \pm 0.83 \\
(106) \\
b\end{array}$ & $\begin{array}{c}26.40 \pm 0.80 \\
(115) \\
b\end{array}$ & $\begin{array}{c}29.30 \pm 2.22 \\
(15) \\
a, b\end{array}$ & $\begin{array}{c}30.60 \pm 2.07 \\
(17) \\
a, b\end{array}$ & $\begin{array}{c}33.90 \pm 1.83 \\
(22) \\
a\end{array}$ & 0.005 \\
\hline $\begin{array}{l}\text { Leptin } \\
(\mathrm{ng} / \mathrm{ml})\end{array}$ & $\begin{array}{c}16.30 \pm 0.85 \\
(313) \\
b\end{array}$ & $\begin{array}{c}16.10 \pm 1.45 \\
(107) \\
b\end{array}$ & $\begin{array}{c}16.80 \pm 1.40 \\
(114) \\
b\end{array}$ & $\begin{array}{c}26.50 \pm 2.60 \\
(15) \\
a, b\end{array}$ & $\begin{array}{c}27.30 \pm 3.43 \\
(19) \\
a\end{array}$ & $\begin{array}{c}24.40 \pm 3.90 \\
(32) \\
b\end{array}$ & 0.0001 \\
\hline $\mathrm{RQ}$ & $\begin{array}{c}0.797 \pm 0.003 \\
(317)\end{array}$ & $\begin{array}{c}0.788 \pm 0.005 \\
\quad(110)\end{array}$ & $\begin{array}{c}0.805 \pm 0.004 \\
\quad(125)\end{array}$ & $\begin{array}{c}0.804 \pm 0.012 \\
(18)\end{array}$ & $\begin{array}{c}0.786 \pm 0.011 \\
(21)\end{array}$ & $\begin{array}{c}0.779 \pm 0.010 \\
(23)\end{array}$ & 0.05 \\
\hline
\end{tabular}

Significant results $(p \leq 0.05)$ are in bold. Means with the same letter were not found to be significantly different by the Fisher's LSD test; -: test not applicable. Number $(N)$ of subjects is indicated in parentheses.

In a search for mutations related to the associations with obesity that we observed for UCP3 in QFS, the seven exons, the 5' UTR, and the intronexon junctions of UCP3 have been sequenced in five subjects homozygote for the GAIVS6 $238 \mathrm{bp}$ allele and five subjects homozygote for the 240-bp allele (Table $5)$. The $\mathrm{C}$ to $\mathrm{T}$ change at nucleotide (nt) -55 of exon $\mathrm{l}$ $\left(5^{\prime}\right.$ UTR-55C $\rightarrow$ T) (32) was detected, and a $\mathrm{C}$ to $\mathrm{T}$ change at nt -36 of intron 5 (IVS4-36T $\rightarrow$ C) was uncovered. The 5'UTR-55C $\rightarrow$ T polymorphism could be partially linked with $\mathrm{Y} 210 \mathrm{Y}(\mathrm{C} \rightarrow \mathrm{T})$, with CT heterozygotes from 5'UTR--55C $\rightarrow$ T corresponding to CT het- erozygotes of $\mathrm{Y} 210 \mathrm{Y}(\mathrm{C} \rightarrow \mathrm{T})$, and $\mathrm{CC}$ homozygotes to TT homozygotes, except for subjects 5 and 8 corresponding to CC and CT, respectively (Table 5). The 5'UTR-55C $\rightarrow$ T polymorphism could also be partially in linkage disequilibrium with GAIVS6 because all 240-240 homozygotes for GAIVS6 are CC at 5'UTR$55 \mathrm{C} \rightarrow \mathrm{T}$, and four of the five 238-238 homozygotes are CT for 5'UTR-55C $\rightarrow$ T, with subject 5 being CC (Table $5)$. On the other hand, only homozygotes for either of the two IVS4-36C $\rightarrow$ T alleles (five subjects IVS4-36C and three others IVS4-36T) were observed among the eight subjects sequenced for this particular polymor-

Table 3. Covariance analysis of the mean value ( \pm standard error) for the phenotypes for the 238-bp allele of GAIVS6 microsatellite of UCP3 gene in QFS.

\begin{tabular}{|c|c|c|c|c|c|c|c|}
\hline \multirow[b]{2}{*}{ Phenotype } & \multicolumn{3}{|c|}{ Genotypes } & \multirow[b]{2}{*}{$p$} & \multicolumn{2}{|c|}{ 238-bp allele } & \multirow[b]{2}{*}{$p$} \\
\hline & $238-238$ & 238-other & Other-other & & Carrier & Noncarrier & \\
\hline $\begin{array}{l}\text { BMI } \\
\left(\mathrm{kg} / \mathrm{m}^{2}\right)\end{array}$ & $\begin{array}{c}26.70 \pm 0.38 \\
(347) \\
a\end{array}$ & $\begin{array}{c}27.00 \pm 0.44 \\
(258) \\
a\end{array}$ & $\begin{array}{c}30.30 \pm 0.79 \\
(79) \\
b\end{array}$ & 0.0001 & $\begin{array}{c}26.80 \pm 0.28 \\
(605)\end{array}$ & $\begin{array}{c}30.30 \pm 0.79 \\
(79)\end{array}$ & 0.0001 \\
\hline $\begin{array}{l}\text { SF6 } \\
(\mathrm{mm})\end{array}$ & $\begin{array}{c}118.20 \pm 3.31 \\
(332) \\
a\end{array}$ & $\begin{array}{c}117.10 \pm 3.85 \\
(246) \\
a\end{array}$ & $\begin{array}{c}148.30 \pm 7.07 \\
(73) \\
b\end{array}$ & 0.0003 & $\begin{array}{c}117.80 \pm 2.50 \\
(578)\end{array}$ & $\begin{array}{c}148.30 \pm 7.06 \\
(73)\end{array}$ & 0.0001 \\
\hline $\begin{array}{l}\text { FM } \\
(\mathrm{kg})\end{array}$ & $\begin{array}{c}21.20 \pm 0.73 \\
(300) \\
a\end{array}$ & $\begin{array}{c}20.70 \pm 0.85 \\
(221) \\
a\end{array}$ & $\begin{array}{c}27.40 \pm 1.72 \\
(54) \\
b\end{array}$ & 0.002 & $\begin{array}{c}21.00 \pm 0.55 \\
(521)\end{array}$ & $\begin{array}{c}27.40 \pm 1.72 \\
(54)\end{array}$ & 0.0005 \\
\hline$\%$ FAT & $\begin{array}{c}27.40 \pm 0.49 \\
(300) \\
a\end{array}$ & $\begin{array}{c}26.90 \pm 0.58 \\
(221) \\
a\end{array}$ & $\begin{array}{c}31.60 \pm 1.17 \\
(54) \\
b\end{array}$ & 0.002 & $\begin{array}{c}27.20 \pm 0.37 \\
(521)\end{array}$ & $31.60 \pm 1.17$ & 0.0004 \\
\hline $\begin{array}{l}\text { Leptin } \\
(\mathrm{ng} / \mathrm{ml})\end{array}$ & $\begin{array}{c}16.30 \pm 0.84 \\
(313) \\
a\end{array}$ & $\begin{array}{c}16.40 \pm 1.00 \\
(221) \\
a\end{array}$ & $\begin{array}{c}26.20 \pm 1.83 \\
(68) \\
b\end{array}$ & 0.0001 & $\begin{array}{c}16.40 \pm 0.64 \\
(534)\end{array}$ & $\begin{array}{c}26.20 \pm 1.83 \\
(66)\end{array}$ & 0.0001 \\
\hline $\mathrm{RQ}$ & $\begin{array}{c}0.797 \pm 0.003 \\
(317)\end{array}$ & $\begin{array}{c}0.797 \pm 0.003 \\
\quad(235)\end{array}$ & $\begin{array}{c}0.789 \pm 0.006 \\
(62)\end{array}$ & 0.48 & $\begin{array}{c}0.797 \pm 0.002 \\
(552)\end{array}$ & $\begin{array}{c}0.789 \pm 0.006 \\
(62)\end{array}$ & 0.23 \\
\hline
\end{tabular}

Significant results $(p \leq 0.05)$ are in bold. Means with the same letter were not found to be significantly different by the Fisher's LSD test; -: test not applicable. Number $(N)$ of subjects is indicated in parentheses. 
Table 4. Covariance analysis of the mean value ( \pm standard error) for the phenotypes for the 240-bp allele of GAIVS6 microsatellite of UCP3 gene in QFS.

\begin{tabular}{|c|c|c|c|c|c|c|c|}
\hline \multirow[b]{2}{*}{ Phenotype } & \multicolumn{3}{|c|}{ Genotype } & \multirow[b]{2}{*}{$p$} & \multicolumn{2}{|c|}{ Genotype } & \multirow[b]{2}{*}{$p$} \\
\hline & $240-240$ & 240-other & Other-other & & $240-240$ & Other & \\
\hline $\begin{array}{l}\text { BMI } \\
\left(\mathrm{kg} / \mathrm{m}^{2}\right)\end{array}$ & $\begin{array}{c}31.80 \pm 1.19 \\
(35) \\
a\end{array}$ & $\begin{array}{c}27.60 \pm 0.58 \\
(146) \\
b\end{array}$ & $\begin{array}{c}26.80 \pm 0.31 \\
(503) \\
b\end{array}$ & 0.0002 & $31.80 \pm 1.19$ & $\begin{array}{c}27.00 \pm 0.28 \\
(649)\end{array}$ & 0.0001 \\
\hline $\begin{array}{l}\text { SF6 } \\
(\mathrm{mm})\end{array}$ & $\begin{array}{c}165.00 \pm 10.82 \\
(31) \\
a\end{array}$ & $\begin{array}{c}125.10 \pm 5.09 \\
(140) \\
b\end{array}$ & $\begin{array}{c}117.20 \pm 2.75 \\
(480) \\
b\end{array}$ & 0.0001 & $\begin{array}{c}165.00 \pm 10.82 \\
(31)\end{array}$ & $\begin{array}{c}119.00 \pm 2.41 \\
(620)\end{array}$ & 0.0001 \\
\hline $\begin{array}{l}\text { FM } \\
(\mathrm{kg})\end{array}$ & $\begin{array}{c}30.20 \pm 2.70 \\
(22) \\
a\end{array}$ & $\begin{array}{c}22.00 \pm 1.14 \\
(123) \\
b\end{array}$ & $\begin{array}{c}21.00 \pm 0.61 \\
(430) \\
b\end{array}$ & 0.004 & $\begin{array}{c}30.20 \pm 2.70 \\
(22)\end{array}$ & $\begin{array}{c}21.30 \pm 0.54 \\
(553)\end{array}$ & 0.001 \\
\hline$\%$ FAT & $\begin{array}{c}33.90 \pm 1.83 \\
(22) \\
a\end{array}$ & $\begin{array}{c}27.90 \pm 0.77 \\
(123) \\
b\end{array}$ & $\begin{array}{c}27.20 \pm 0.41 \\
(430) \\
b\end{array}$ & 0.002 & $\begin{array}{c}33.90 \pm 1.83 \\
(22)\end{array}$ & $\begin{array}{c}27.40 \pm 0.36 \\
(553)\end{array}$ & 0.0005 \\
\hline $\begin{array}{l}\text { Leptin } \\
(\mathrm{ng} / \mathrm{ml})\end{array}$ & $\begin{array}{c}26.50 \pm 2.66 \\
(32) \\
a\end{array}$ & $\begin{array}{c}17.80 \pm 1.35 \\
(126) \\
b\end{array}$ & $\begin{array}{c}16.70 \pm 0.72 \\
(442) \\
b\end{array}$ & 0.002 & $\begin{array}{c}26.50 \pm 2.66 \\
(32)\end{array}$ & $\begin{array}{c}16.90 \pm 0.63 \\
(568)\end{array}$ & 0.0006 \\
\hline RQ & $\begin{array}{c}0.779 \pm 0.010 \\
(22)\end{array}$ & $\begin{array}{c}0.787 \pm 0.004 \\
\quad(127)\end{array}$ & $\begin{array}{c}0.799 \pm 0.002 \\
(451)\end{array}$ & 0.01 & $\begin{array}{c}0.780 \pm 0.010 \\
(22)\end{array}$ & $\begin{array}{c}0.797 \pm 0.002 \\
(578)\end{array}$ & 0.11 \\
\hline
\end{tabular}

Significant results $(p \leq 0.05)$ are in bold. Means with the same letter were not found to be significantly different by the Fisher's LSD test; -: test not applicable. Number $(N)$ of subjects is indicated in parentheses.

phism. In this case, GAIVS6 238-bp and 240-bp homozygotes corresponded, respectively, to IVS4$36 \mathrm{C} \rightarrow \mathrm{T}$ CC and TT homozygotes, except for subject 6 (Table 5). RFLP study showed that the Y210Y (C-T) variant was not associated with adiposity in QFS.

\section{Discussion}

We have observed an association between a microsatellite in the sixth intron of UCP3 gene and obesity. For instance, the 240-bp allele was observed at a greater frequency in obese subjects $\left(\mathrm{BMI}>30 \mathrm{~kg} / \mathrm{m}^{2}\right)$, and homozygotes for the 240-bp allele showed higher mean values for BMI, SF6, FM, $\%$ FAT, and leptin, with a trend toward a lower RQ. In contrast, the most common 238-bp allele showed a lower frequency in subjects with BMI $>35 \mathrm{~kg} / \mathrm{m}^{2}$, and was associated with lower BMI, SF6, FM, $\%$ FAT, and leptin mean values. Differences were shown to be highly significant ( $p$ down to 0.0001 ).

Table 5. Polymorphisms detected in UCP3 gene by sequencing of 5'UTR, exons, and exon-intron junctions of subjects homozygote for either GAIVS6 238- or 240-bp alleles.

\begin{tabular}{|c|c|c|c|c|c|}
\hline \multirow[b]{2}{*}{ Subjects } & \multirow{2}{*}{$\begin{array}{c}\text { BMI } \\
\left(\mathrm{kg} / \mathrm{m}^{2}\right)\end{array}$} & \multicolumn{3}{|c|}{ Polymorphisms } & \multirow{2}{*}{$\begin{array}{l}\text { GAIVS6 } \\
\text { Genotype }\end{array}$} \\
\hline & & 5UTR-55C $\rightarrow \mathrm{T}$ & IVS4-36C $\rightarrow T$ & $\overline{\mathrm{Y} 210 \mathrm{Y}(\mathrm{C} \rightarrow \mathrm{T})^{a}}$ & \\
\hline 1 & NA & CT & $\mathrm{CC}$ & $\mathrm{CT}$ & $238-238$ \\
\hline 2 & 18.6 & $\mathrm{CT}$ & NA & $\mathrm{CT}^{b}$ & $238-238$ \\
\hline 3 & 21.0 & CT & $\mathrm{CC}$ & $\mathrm{CT}$ & $238-238$ \\
\hline 4 & 23.4 & CT & $\mathrm{CC}$ & $\mathrm{CT}$ & $238-238$ \\
\hline 5 & 25.4 & $\mathrm{CC}$ & CC & CC & $238-238$ \\
\hline 6 & 25.2 & $\mathrm{CC}$ & $\mathrm{CC}$ & TT & $240-240$ \\
\hline 7 & 25.6 & $\mathrm{CC}$ & TT & TT & $240-240$ \\
\hline 8 & 37.8 & $\mathrm{CC}$ & NA & $\mathrm{CT}^{b}$ & $240-240$ \\
\hline 9 & 40.8 & $\mathrm{CC}$ & TT & TT & $240-240$ \\
\hline 10 & 42.9 & $\mathrm{CC}$ & TT & TT & $240-240$ \\
\hline
\end{tabular}

${ }^{a}$ All genotypes confirmed by RFLP.

${ }^{b}$ Genotypes by sequencing not available.

NA, not available. 
Results for leptin level did not remain significant when values were adjusted for a fat mass indicator showing that the observed UCP3 association with leptin might be secondary to fat accumulation. Indeed, a positive correlation has been reproducibly observed between circulating leptin and fat mass (33). These results suggested that the 240 -bp allele, in the absence of the 238-bp allele, allowed high adiposity and obesity. For instance, only the homozygotes for the 240-bp allele showed significant effects on adiposity-related phenotypes, which indicates that two copies of this allele are needed to express a higher adiposity. However, not all the 240-bp homozygous subjects showed, individually, this higher propensity to store fat (data not shown), which means that other factors, genetic or environmental, are needed to express the obesity phenotype.

In mice, the knockout of the UCP3 gene did not induce an obesity phenotype $(12,13)$. This discrepancy with our results might be explained by the fact that in rodents, in contrast to humans, a possible decrease in muscle thermogenesis might be compensated for by brown adipose tissue. It is also possible that the complete absence of expression of UCP3, as in knockout mice, would induce compensatory mechanisms in contrast to an allele with altered functions such as the 240-bp allele we observed in humans.

It is also possible that the effect of the GAIVS6 microsatellite could come from another linked mutation in the UCP3 coding or promoter regions, or from a closed gene. Other UCP3 polymorphisms studied in the QFS showed no association with obesity. The UCP3 V102I $(\mathrm{G} \rightarrow \mathrm{A})$ polymorphism showed no relation with obesity in an African-American population (19), and no variation in whites (18) as we observed in QFS. Similarly, in a French cohort, the UCP3 Y2 $10 \mathrm{Y}(\mathrm{C} \rightarrow \mathrm{T})$ polymorphism showed comparable genotype frequencies between obese and normal weight subjects (22), as also observed in the QFS. GAIVS6 seems to be in partial linkage with 5'UTR-55C $\rightarrow \mathrm{T}$, because, among the 10 sequenced subjects, the 240-240 bp homozygotes for GAIVS6 all carried the CC genotype for 5'UTR-55C $\rightarrow$ T whereas four subjects among the five GAIVS6 238-238 homozygotes were CT heterozygotes for the 5'UTR-55C $\rightarrow$ T polymorphism. The CC genotype at this polymorphism has been reported to be associated with a lower BMI among morbidly obese patients and, in CC individuals, BMI was negatively associated with physical activity (23), and positively associated with a greater waist-to-hip ratio (34). The Y99Y polymorphism showed also a positive association with a greater BMI (22). Our results do not enable us to draw any conclusions about the possible effect of the 5'UTR-55C $\rightarrow$ T polymorphism because three CC subjects showed low BMI, and three others high BMI. The complete genotyping of the QFS cohort subjects is necessary to draw any conclusions regarding the relationships between polymorphism
5'UTR-55C $\rightarrow$ T of UCP3 and BMI. On the other hand, it is unlikely that the observed association between UCP3 and adiposity could come from a linkage disequilibrium with the neighboring gene UCP2 because two polymorphisms (A55V and exon $8 \mathrm{I} / \mathrm{D}$ ) showed no association with adiposity in the QFS. Finally, it could eventually be hypothesized that the effect of the GAIVS 6 microsatellite could come from a linked mutation in the promoter. Clearly, further studies are needed to test this hypothesis.

The UCP3 gene generates two mRNA termination variants, producing a short and a long form of the protein $(6,35)$. UCP $3_{s}$ lacks the VIth potential transmembrane domain and a large part of the putative nucleotide binding domain of UCP3. It was hypothesized that the $\mathrm{UCP}_{3}$ s protein was either inactive, because of the absence of the VIth transmembrane domain, or constitutively active, because of the absence of inhibition by GDP (36). In fact, Hinz et al. (36) observed that UCP3 3 had a higher intrinsic activity than $U C P 3_{L}$, whereas another study (37) concluded that UCP3 3 had modestly reduced activity compared to $\mathrm{UCP}_{\mathrm{L}}$. The reason why our microsatellite polymorphism in IVS6 could modify UCP3 function is difficult to explain. Point mutations in the vicinity of splice junctions are the cause of many human genetic diseases (38). Because of its location in intron 6 downstream the stop codon used for the production of UCP $3_{s}$, GAIVS6 could eventually alter the efficiency of the intron 6 splicing for the UCP $3_{L}$ mRNA synthesis and therefore modify the proportions of the two UCP3 forms and UCP3 activity. Although a reported polymorphism in the splice donor junction of exon 6 in humans was not found to be clearly associated with adiposity $(18,19)$ or uncoupling activity of UCP3 (39), we cannot exclude that the GAIVS6 polymorphism affects $\mathrm{UCP}_{\mathrm{L}}$ synthesis. The significance of the GAIVS6 on UCP3 biological activity should be investigated in further studies.

It has been shown that UCP3, like UCP1, has an uncoupling function and increases thermogenesis in transfected cells (9), although its physiologic role is not known. Other potential roles for UCP3 in the regulation of body temperature and body weight as well as in fatty acid oxidation (40) have also been suggested. UCP3 is mainly expressed in skeletal muscle and this tissue plays an important role in adrenaline-induced thermogenesis (10), energy homeostasis, and substrate oxidation. In humans, an increase of RQ in subjects heterozygous for an exon 6 splice donor mutation (18), and a correlation between $\mathrm{UCP} 3_{\mathrm{L}}$ mRNA and metabolic rate during sleep (17), have been reported. A high RQ value indicates a low rate of fat oxidation, and may represent a predisposition for weight gain (41). However, in QFS, the 240-240 bp homozygotes have a slightly but not significantly lower RQ for a higher adiposity than the other genotypes. Because the RQ value of 0.776 observed for the 240-bp allele homozygotes 
was low compared to values of 0.836 and 0.905 reported for obese diabetic subjects (18), the biological significance of this lower RQ in obese subjects of QFS remains to be clarified.

In summary, the present study showed that the uncoupling protein 3 gene is involved in human obesity. The GAIVS6 UCP3 polymorphism studied is associated with higher adiposity, and this supports the hypothesis of a role in fatty acid transport and metabolism. Because of its location, the GAIVS6 microsatellite could have an impact on the relative production of the long and short forms of the UCP3 protein and, thus perhaps, on UCP3 activity.

\section{Acknowledgments}

The authors acknowledge the contribution of Chantal Paré for laboratory work, and Claude Leblanc and Christian Couture for computer and software assistance. The authors also express their gratitude to Prof. Stylianos E. Antonarakis, who detected the initial GAIVS6 DNA sequence in UCP3. Thanks are also expressed to Guy Fournier, Lucie Allard, and Dr. Germain Thériault for their contribution to the data collection of this study. This work was supported by the Medical Research Council of Canada (MT-13960) and the Swiss National Science Foundation grant $\mathrm{N}^{\circ} 31-54306.98$.

\section{References}

1. Kuczmarski RJ, Flegal KM, Campbell SM, Johnson CL. (1994) Increasing prevalence of overweight among US adults. The National Health and Nutrition Examination Surveys, 1960 to 1991. JAMA 272: 205-211.

2. Bray GA. (1992) Pathophysiology of obesity. Am. J. Clin. Nutr. 55(2 Suppl): 488S-494S.

3. Bouchard C. (1994) Genetics of obesity: overview and research directions. In: C. Bouchard, ed. The Genetics of Obesity. Boca Raton, FL: CRC Press, pp. 223-233.

4. Klaus S, Casteilla L, Bouillaud F, Ricquier D. (1991). The uncoupling protein UCP: a membraneous mitochondrial ion carrier exclusively expressed in brown adipose tissue. Int. $J$. Biochem. 23: 791-801.

5. Fleury C, Neverova M, Collins S, et al. (1997) Uncoupling protein-2: a novel gene linked to obesity and hyperinsulinemia. Nat. Genet. 15: 269-272.

6. Boss O, Samec S, Paoloni-Giacobino A, et al. (1997) Uncoupling protein-3: a new member of the mitochondrial carrier family with tissue-specific expression. FEBS Lett. 408: 39-42.

7. Pecqueur C, Cassard-Doulcier AM, Raimbault S, et al. (1999) Functional organization of the human uncoupling protein-2 gene, and juxtaposition to the uncoupling protein-3 gene. Biochem. Biophys. Res. Commun. 255: 40-46.

8. Muzzin P, Boss O, Giacobino JP. (1999) Uncoupling protein 3: its possible biological role and mode of regulation in rodents and humans. J. Bioenerg. Biomembr. 31: 467-473.

9. Gong DW, He Y, Karas M, Reitman M. (1997) Uncoupling protein-3 is a mediator of thermogenesis regulated by thyroid hormone, beta3-adrenergic agonists, and leptin. J. Biol. Chem. 272: 24129-24132.

10. Simonsen L, Stallknecht B, Bulow J. (1993) Contribution of skeletal muscle and adipose tissue to adrenaline-induced thermogenesis in man. Int. J. Obes. Relat. Metab. Disord. 17(Suppl 3): S47-S51; discussion S68.
11. Clapham J, Arch J, Chapman H, et al. (2000) Mice overexpressing human uncoupling protein-3 in skeletal muscle are hyperphagic and lean. Nature 406: 415-418.

12. Vidal-Puig AJ, Grujic D, Zhang CY, et al. (2000) Energy metabolism in uncoupling protein 3 gene knockout mice. J. Biol. Chem. 275: 16258-16266.

13. Gong D, Monemdjou S, Gavrilova O, et al. (2000) Lack of obesity and normal response to fasting and thyroid hormone in mice lacking uncoupling protein-3. J. Biol. Chem. 275: $16251-16257$.

14. Samec S, Seydoux J, Dulloo AG. (1998) Role of UCP homologues in skeletal muscles and brown adipose tissue: mediators of thermogenesis or regulators of lipids as fuel substrate? FASEB J. 12: 715-724.

15. Khalfallah Y, Fages S, Laville M, Langin D, Vidal H. (2000) Regulation of uncoupling protein-2 and uncoupling protein-3 mRNA expression during lipid infusion in human skeletal muscle and subcutaneous adipose tissue. Diabetes 49: 25-31.

16. Comuzzie AG, Almasy L, Cole SA, et al. (2000) Linkage exclusion analysis of the chromosome 11 region containing UCP2 and UCP3 with obesity-related phenotypes in Mexican Americans. Int. J. Obes. Relat. Metab. Disord. 24: 1065-1068.

17. Schrauwen P, Xia J, Bogardus C, Pratley RE, Ravussin E. (1999) Skeletal muscle uncoupling protein 3 expression is a determinant of energy expenditure in Pima Indians. Diabetes 48: 146-149.

18. Argyropoulos G, Brown AM, Willi SM, et al. (1998) Effects of mutations in the human uncoupling protein 3 gene on the respiratory quotient and fat oxidation in severe obesity and type 2 diabetes. J. Clin. Invest. 102: 1345-1351.

19. Chung W, Luke A, Cooper R, et al. (1999) Genetic and physiologic analysis of the role of uncoupling protein 3 in human energy homeostasis. Diabetes 48: 1890-1895.

20. Urhammer SA, Dalgaard LT, Sorensen TI, et al. (1998) Organisation of the coding exons and mutational screening of the uncoupling protein 3 gene in subjects with juvenile-onset obesity. Diabetologia 41: 241-244.

21. Walder K, Norman RA, Hanson RL, et al. (1998) Association between uncoupling protein polymorphisms (UCP2-UCP3) and energy metabolism/obesity in Pima Indians. Hum. Mol. Genet. 7: 1431-1435.

22. Otabe S, Clement K, Dubois S, et al. (1999) Mutation screening and association studies of the human uncoupling protein 3 gene in normoglycemic and diabetic morbidly obese patients. Diabetes 48: 206-208.

23. Otabe S, Clement K, Dina C, et al. (2000) A genetic variation in the 5 'flanking region of the UCP3 gene is associated with body mass index in humans in interaction with physical activity. Diabetologia 43: 245-249.

24. Bouchard C. (1996) Genetic epidemiology, association and sib-pair linkage: results from the Quebec Family Study. In: Bray GA, ed. Molecular and Genetic Aspects of Obesity. Baton Rouge: Louisiana State University Press, pp. 470-481.

25. Behnke AR, Wilmore WJ. (1974) Evaluation and regulation of body build and composition. Englewood Cliffs, NJ: Prentice-Hall.

26. Siri WE. (1976) The gross composition of the body. In: Lawrence JH, Tobias CA, ed. Advances in Biological and Medical Physics. New York: Academic Press, pp. 239-280.

27. Deriaz O, Dionne F, Perusse L, et al. (1994) DNA variation in the genes of the $\mathrm{Na}, \mathrm{K}$-adenosine triphosphatase and its relation with resting metabolic rate, respiratory quotient, and body fat. J. Clin. Invest. 93: 838-843.

28. Desbuquois B, Aurbach GD. (1971) Use of polyethylene glycol to separate free and antibody-bound peptide hormones in radioimmunoassays. J. Clin. Endocrinol. Metab. 33: 732-738.

29. Richterich R, Dauwalder H. (1971) [Determination of plasma glucose by hexokinase-glucose-6-phosphate dehydrogenase method]. Schweiz Med. Wochenschr. 101: 615-618.

30. Boss O, Giacobino JP, Muzzin P. (1998) Genomic structure of uncoupling protein-3 (UCP3) and its assignment to chromosome 1lq13. Genomics 47: 425-426. 
31. Chagnon YC, Wilmore JH, Borecki IB, et al. (2000) Associations between the leptin receptor gene and adiposity in middle-aged Caucasian males from the HERITAGE family study. J. Clin. Endocrinol. Metab. 85: 29-34.

32. Garenc C, Perusse L, Gagnon J, et al. (2000) Linkage and association studies of the lipoprotein lipase gene with postheparin plasma lipase activities, body fat, and plasma lipid and lipoprotein concentrations: the HERITAGE Family Study. Metabolism 49: 432-439.

33. Maffei M, Halaas J, Ravussin E, et al. (1995) Leptin levels in human and rodent: measurement of plasma leptin and ob RNA in obese and weight-reduced subjects. Nat. Med. 1: 1155-1161.

34. Cassell PG, Saker PJ, Huxtable SJ, et al. (2000) Evidence that single nucleotide polymorphism in the uncoupling protein 3 (UCP3) gene influences fat distribution in women of European and Asian origin. Diabetologia 43: 1558-1564.

35. Solanes G, Vidal-Puig A, Grujic D, Flier JS, Lowell BB. (1997) The human uncoupling protein-3 gene. Genomic structure, chromosomal localization, and genetic basis for short and long form transcripts. J. Biol. Chem. 272: 2543325436 .
36. Hinz W, Gruninger S, De PA, Chiesi M. (1999) Properties of the human long and short isoforms of the uncoupling protein-3 expressed in yeast cells. FEBS Lett. 462: 411-415.

37. Hagen T, Zhang C, Slieker L, Chung W, Leibel R, Lowell B. (1999) Assessment of uncoupling activity of the human uncoupling protein 3 short form and three mutants of the uncoupling protein gene using a yeast heterologous expression system. FEBS Lett. 454: 201-206.

38. Krawczak M, Reiss J, Cooper DN. (1992) The mutational spectrum of single base-pair substitutions in mRNA splice junctions of human genes: causes and consequences. Hum. Genet. 90: 41-54.

39. Brown A, Dolan J, Willi S, Garvey W, Argyropoulos G. (1999) Endogenous mutations in human uncoupling protein 3 alter its functional properties. FEBS Lett. 464: 189-193.

40. Skulachev VP. (1998) Uncoupling: new approaches to an old problem of bioenergetics, Biochim. Biophys. Acta 1363: 100-124.

41. Zurlo F, Lillioja S, Esposito-Del Puente A, et al. (1990) Low ratio of fat to carbohydrate oxidation as predicator of weight gain: study of 24-h RQ. Am. J. Physiol. 259: E650-E657. 